\title{
Perancangan Aplikasi Peminjaman Lapangan Basket Universitas Kristen Satya Wacana Berbasis WEB
}

\author{
Vemytha Kalalinggi ${ }^{1}$, Evangs Mailoa, S.Kom., M.Cs. ${ }^{2}$ \\ ${ }^{1,2} \mathrm{Jl}$. Diponegoro 52 - 60, Salatiga 50711, Indonesia \\ ${ }^{3}$ Jurusan Teknik Informatika, FTI UKSW, Salatiga \\ E-mail: 1672016205@student.uksw.edu, 2evangs.mailoa@uksw.edu
}

\begin{abstract}
Abstrak
Proses pencatatan jadwal penggunaan dan peminjaman lapangan basket di Universitas Kristen Satya Wacana merupakan sesuatu hal yang penting mengingat banyaknya kegiatan mahasiswa yang diselenggarakan bertempat di lapangan basket dan peminjaman yang selama ini dilakukan masih menggunakan cara manual atau offline yang membutuhkan waktu cukup lama sehingga proses peminjaman lapangan membutuhkan waktu yang cepat dan efektif dalam membantu penyelenggara kegiatan dalam melihat jadwal yang kosong dan melakukan pemesanan lapangan. Berdasarkan permasalahan tersebut, penulis merancang sebuah aplikasi peminjaman lapangan basket di Universitas Kristen Satya Wacana (UKSW) yang berbasis Web. Aplikasi ini dibuat untuk mempermudah civitas akademika UKSW dalam melakukan pengelolaan jadwal penggunaan dan proses peminjaman lapangan. Perancangan aplikasi ini menggunakan Unifed Modelling Language (UML) dan Prototype Model sebagai metode penelitian yang digunakan oleh penulis. Aplikasi ini dibuat menggunakan Bahasa pemrograman PHP, HTML dan MySQL sebagai database. Hasil akhir dari penelitian ini berupa sebuah aplikasi peminjaman berbasis web yang telah diuji menggunakan metode perhitungan skala likert sehingga dihasilkan sebuah aplikasi yang memudahkan civitas akademika UKSW dalam melakukan proses peminjaman.
\end{abstract}

Kata kunci: Peminjaman Lapangan, Web, Prototype Model, UML, Skala Likert

\begin{abstract}
Recording the schedule of basketball court usage at Satya Wacana Christian University is important considering the large number of student activities held at this court which currently done in manual and offline recording method that takes time to confirmed incoming reservation from personal or event organizers. Looking at this problem and to provide an efficient and time effective application, the author designed a basketball court schedule management application at SWCU based on the web. This application purpose to ease the SWCU academic community to manage the schedule of basketball court usage. This application design using Unified Modelling Language (UML) and Prototype Model as the research-based. While the programming language using PHP, HTML and, MySQL as databased. The final results of this research would be a web-based schedule management application that has been tested using Linkert scale calculation which could help and ease UKSW academic community to make a basketball court usage reservation.
\end{abstract}

Keywords: Court Reservation, Web, Prototype, Model, UML, Likert Scale 


\section{PENDAHULUAN}

Lapangan merupakan tempat atau tanah yang luas (biasanya rata) dan Lapangan Basket merupakan lapangan untuk berlatih atau bermain basket [1], namun Lapangan Basket Universitas Kristen Satya Wacana (UKSW) tidak hanya berfungsi sebagai tempat untuk berlatih basket tetapi dapat digunakan untuk berlatih voli dan melaksanakan kegiatan - kegiatan kampus seperti aktivitas kemahasiswaan maupun kegiatan yang diselenggarakan oleh pihak dosen dan staff UKSW. Kebutuhan akan lapangan yang semakin bertambah disaat waktu pelaksanaan kegiatan menyebabkan pemesanan dan penjadwalan terhadap kebutuhan lapangan semakin meningkat. Berdasarkan data rekapan departemen Fasilitas Kemahasiswaan yang dibawahi oleh Senat Mahasiswa Universitas (SMU) UKSW, dapat dilihat bahwa pada Periode 2018 - 2019 (Oktober 2018 - April 2019), jumlah total penggunaan lapangan basket UKSW yaitu 659 peminjaman yang telah melalui proses sinkronisasi. Peminjaman dan penjadwalan lapangan basket UKSW saat ini masih menggunakan cara yang manual yaitu pemesan harus melakukan konfirmasi kepada pihak BMK sebagai bagian yang mengurus sarana prasarana kampus dan Departemen Fasilitas Kemahasiswaan baik secara langsung atau telepon maupun media sosial seperti WhatsApp terkait pengecekan waktu kosong penggunaan lapangan. Pada saat proses peminjaman dibutuhkan waktu sekitar satu sampai dua hari untuk sekedar menunggu konfirmasi ketersediaan waktu kosong karena petugas harus melihat dan memeriksa jadwal penggunaan lapangan, dan pembuatan jadwal penggunaan lapangan oleh Departemen Fasilitas Kemahasiswaan masih dilakukan dengan penjadwalan yang manual yaitu berupa tabel file excel.

Berdasarkan hal tersebut, diperlukan perancangan dan pembuatan suatu sistem yang dapat mempermudah dan mempercepat proses peminjaman lapangan basket UKSW. Oleh karena itu, pengguna dapat memperoleh kemudahan dalam hal peminjaman dan penjadwalan lapangan basket melalui perancangan dan pembuatan suatu aplikasi peminjaman lapangan basket berbasis web. Aplikasi berbasis website di era milenial saat ini semakin berkembang dengan pesat dan mempermudah para pengguna dalam melakukan pencarian sehingga proses peminjaman menjadi lebih cepat dan mudah dikarenakan pemesan tidak harus menunggu untuk mengetahui jadwal penggunaan lapangan basket yang kosong dan tidak perlu datang ke kantor SMU untuk melakukan konfirmasi peminjaman tetapi pemesan dapat melihat jadwal penggunaan lapangan yang kosong dan melakukan konfirmasi peminjaman langsung melalui website [2].

Penelitian yang pernah dilakukan oleh Aryi Adriyan Ruse dan Evangs Mailoa dengan judul Perancangan Aplikasi Pemesanan Lapangan Futsal Berbasis Web Di Salatiga. Permasalahan yang menjadi latar belakang penelitian adalah pemesanan lapangan futsal yang masih menggunakan cara manual yaitu pengguna harus datang langsung ke tempat penyewaan lapangan futsal atau menghubungi via telepon. Tujuan penelitian tersebut yaitu menghasilkan sebuah sistem pemesanan lapangan futsal yang dapat memudahkan pengguna dalam mengetahui jadwal dan melakukan pemesanan lapangan futsal. Fitur yang dirancang dalam penelitian ini yaitu form login, form pemesanan lapangan futsal, form pendataan lapangan futsal, form halaman registrasi dan form jadwal lapangan [3].

Penelitian yang pernah dilakukan oleh Sularno dan Nori Sahrun dengan judul Perancangan Dan Implementasi Sistem Informasi Manajemen Aset Pada Pemerintah Kabupaten Merangin Menggunakan Bahasa Pemrograman PHP dan MySQL. Permasalahan yang menjadi latar belakang penelitian adalah sistem pengolahan data asset yang masih mengacu pada sistem manual dengan menggunakan berkas - berkas sebagai sarana pendokumentasian data. Pengolahan data dengan cara ini dinilai banyak menimbulkan masalah pada pemrosesan data asset sehingga tidak diketahui dengan pasti berapa jumlah barang atau peralatan kantor yang masih tersedia. Tujuan penelitian tersebut yaitu merancang sebuah sistem yang dapat mengelola manajemen asset dan memudahkan dalam memonitoring data asset pemerintah Kabupaten

Kalalinggi, et., al (Perancangan Aplikasi Peminjaman Lapangan Basket Universitas Kristen Satya Wacana Berbasis WEB) 
Merangin. Fitur yang dirancang dalam penelitian ini yaitu form halaman utama, form halaman melihat berita, form halaman melihat sejarah, form halaman melihat data asset, form halaman pilihan berita dan form halaman pilihan profil [4].

Penelitian yang pernah dilakukan oleh Faridi, Maryanah Safitri dan Pradiko Roliwinsyah Matusin dengan judul Sistem Aplikasi Peminjaman Dokumen Customer Berbasis Web Pada PT. Lippo Karawaci, Tbk. Permasalahan yang menjadi latar belakang penelitian adalah tingginya intensitas peminjaman dokumen customer dan terdapat peminjam yang tidak bersedia menandatangani log book peminjaman serta data peminjam hanya ditulis dalam sebuah buku sehingga memungkinkan terjadinya kerusakan atau kehilangan dokumen. Tujuan penelitian tersebut yaitu membangun sistem monitoring peminjaman dan pengembalian dokumen customer berbasis web yang dapat digunakan oleh seorang filing officer. Fitur yang dirancang dalam penelitian ini yaitu form login, form tambah dokumen, form menu home, form tambah dokumen, form input data peminjaman dan form tambah pengguna [5].

Aplikasi peminjaman lapangan basket ini dibuat untuk memenuhi kebutuhan civitas akademika Universitas Kristen Satya Wacana dalam melakukan peminjaman lapangan secara online dan aplikasi peminjaman lapangan basket dapat mempermudah pihak kampus dalam mengelola dan mengatur jadwal penggunaan lapangan basket.

\section{METODE PENELITIAN}

\subsection{Tinjauan Pustaka}

\subsubsection{Website}

Website merupakan suatu aplikasi yang dapat diakses melalui jaringan internet atau intranet. Website berisikan dokumen multimedia seperti teks, animasi, gambar atau video yang menggunakan protokol HTTP (Hypertext Transfer Protocol). Pengguna dituntun untuk menemukan informasi menggunakan halaman - halaman yang tersedia dalam dokumen web. Halaman - halaman web yang dibuat membentuk sebuah rangkaian yang saling terikat dan terhubung. Hubungan antara suatu halaman disebut hyperlink, sedangkan teks yang digunakan sebagai media penghubung disebut hypertext [6] [7] [8].

\subsubsection{PHP}

PHP atau (Hypertext Preprocessor) merupakan sebuah bahasa pemrograman open source yang dapat digunakan pada berbagai system operasi seperti Linux, Unix, Macintosh atau Windows. PHP adalah sebuah bahasa pemrograman yang berbentuk scripting dan memiliki sistem kerja yang interpreter bukan compiler. PHP dibuat untuk halaman web yang dinamis, sehingga saat informasi yang diterima oleh client selalu yang terbaru karena halaman website yang ditampilkan dibuat saat halaman tersebut diminta oleh client [7] [8].

\subsubsection{MySQL}

MySQL merupakan salah satu database yang paling digemari oleh para programmer web dengan alasan bahwa database ini sangat kuat dan cukup stabil untuk digunakan sebagai media penyimpanan. Hal ini terbukti untuk query yang dilakukan oleh single user MySQL bisa sepuluh kali lebih cepat dari PostgreSQL dan lima kali lebih cepat dibandingkan Interbase. MySQL didistribusikan secara gratis dibawah license GPL (General Public License), sehingga setiap orang bebas untuk menggunakan MySQL namun tidak boleh dijadikan produk turunan yang bersifat close source atau komersial [4] [7] [8]. 


\subsubsection{Metode Prototype}

Metode prototype dimulai dengan mendengarkan kebutuhan user sehingga pengembang dalam mengidentifikasi persyaratan yang diperlukan dan selanjutnya akan digunakan untuk membuat rancangan aplikasi. Rancangan aplikasi yang telah dirancang akan dievaluasi terlebih dahulu oleh user. Aplikasi yang telah dievaluasi oleh user akan dijadikan sebagai acuan untuk membuat aplikasi yang akan dijadikan sebagai output dalam penelitian ini. Prototype adalah versi awal dari sistem perangkat lunak yang digunakan untuk membuat konsep - konsep, percobaan rancangan dan menemukan berbagai masalah dan solusi yang dapat digunakan. Sasaran metode prototype yaitu menyediakan umpan balik yang cepat dari pengguna terhadap pengembang serta membantu menggambarkan kebutuhan pengguna terhadap sasaran yang akan dicapai [9] [10] [11].

\subsection{Metode Pengembangan Sistem}

Penelitian yang dilakukan melalui beberapa tahap, yaitu:

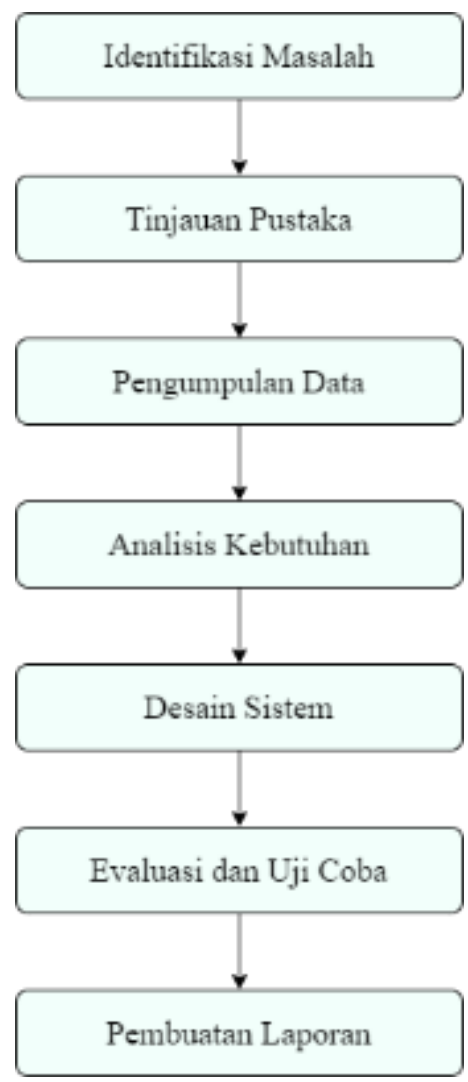

Gambar 1. Tahap - tahap Penelitian

Gambar 1 merupakan tahap - tahap penelitian yang dilakukan oleh penulis. Tahapan tersebut secara rinci, sebagai berikut:

1) Identifikasi Masalah

Tahap awal dalam penelitian ini adalah merumuskan masalah yang dijadikan sebagai objek penelitian. Perumusan masalah dilakukan terlebih dahulu dengan melihat kondisi actual di lapangan. Setelah melakukan perumusan masalah, selanjutnya menentukan tujuan penelitian. Tujuan penelitian ini merupakan sasaran yang ingin diwujudkan dari penyelesaian permasalahan yang diteliti.

Kalalinggi, et., al (Perancangan Aplikasi Peminjaman Lapangan Basket Universitas Kristen Satya Wacana Berbasis 
2) Tinjauan Pustaka

Tinjauan pustaka dilakukan dalam rangka mencari literatur pendukung penelitian ini. Pada tahap ini dijelaskan dengan mengunjungi dan mempelajari website atau situs-situs yang berhubungan dengan sistem peminjaman berbasis web, teori-teori, untuk pengumpulan data dan tools yang digunakan oleh penulis.

3) Metode Pengumpulan Data

Metode yang digunakan untuk mengumpulkan data pada penelitian ini ada dua cara yaitu dengan melakukan observasi. Observasi digunakan untuk memperoleh dan mengumpulkan data yang dibutuhkan dalam perancangan, pengembangan dan proses yang diterapkan dalam peminjaman lapangan. Pengamatan ini dilakukan di departemen Fasilitas Kemahasiswaan Senat Mahasiswa Universitas Universitas Kristen Satya Wacana yang merupakan salah satu departemen yang bertugas untuk mengatur peminjaman lapangan dan proses peminjaman saat ini masih dilakukan secara manual, seperti pengguna harus menghubungi anggota departemen untuk mengetahui jadwal penggunaan lapangan, serta data - data yang tidak terorganisir dan kurang efektif karena masih menggunakan Ms. Excel.

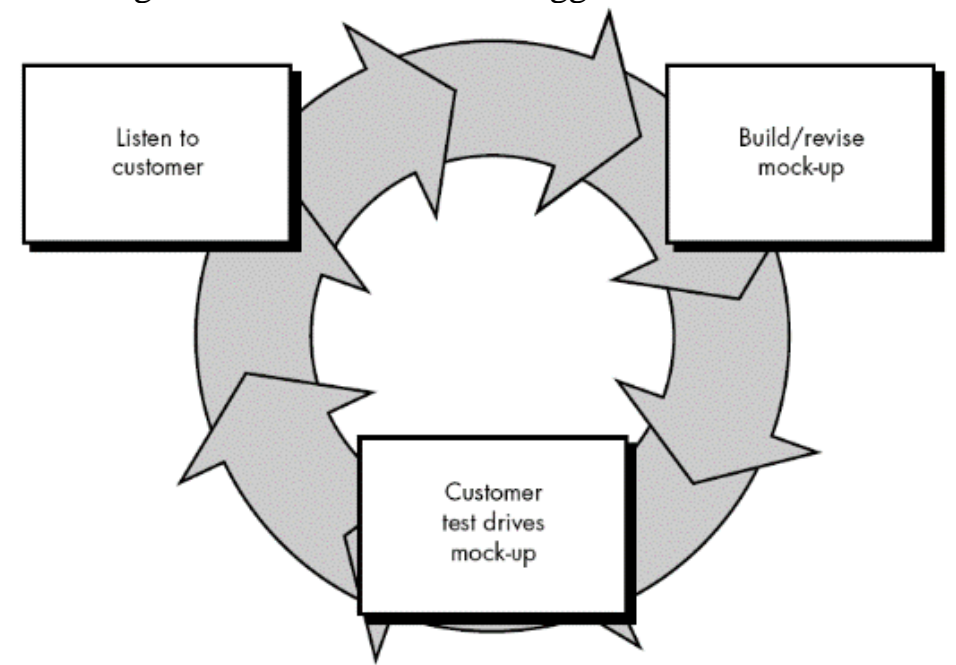

Gambar 2. Prototype Model [9]

4) Dalam proses perancangan dan pembuatan sistem, metode yang digunakan yaitu prototype model. Prototype model didalam penelitian ini bertujuan untuk mendapatkan gambaran alur sistem yang saat ini diterapkan dan dapat diimplementasikan kedalam sebuah aplikasi. Metode ini sebagai langkah awal untuk memberikan penyamaan persepsi dan pemahaman awal akan proses dasar sistem yang akan dikembangkan, sehingga ada komunikasi yang baik antara penulis dan pengguna sistem.

5) Analisis Kebutuhan

Analisis kebutuhan aplikasi atau tahap listen to customer dilakukan untuk mengetahui kebutuhan pengguna terhadap aplikasi yang dikembangkan. Hal ini perlu dilakukan agar aplikasi yang dikembangkan sesuai dengan kebutuhan pengguna. Dibagian ini juga dijelaskan siapa saja yang akan menggunakan aplikasi ini, dan informasi apa saja yang digunakan oleh mereka. Pada tahap ini, penulis melakukan wawancara kepada pihak pengelola lapangan basket UKSW untuk mendapatkan data dan informasi terkait sistem peminjaman lapangan, proses penjadwalan, dan proses peminjaman. Selain itu, penulis melakukan wawancara kepada beberapa mahasiswa yang biasa menggunakan lapangan basket UKSW untuk mendapatkan informasi terkait pengecekan jadwal penggunaan lapangan dan proses melakukan peminjaman lapangan.

Kalalinggi, et., al (Perancangan Aplikasi Peminjaman Lapangan Basket Universitas Kristen Satya Wacana Berbasis WEB) 
6) Desain Sistem

Desain sistem dilakukan untuk membuat perancangan sistem yang akan diusulkan. Perancangan yang dilakukan meliputi, perancangan tampilan user, perancangan basis data untuk manajemen file sehingga menjadi lebih teratur, kemudian melakukan perancangan coding program. Berdasarkan data dan kebutuhan sistem yang telah dikumpulkan, selanjutnya dilakukan tahap build/revise mock-up yang merupakan tahap dasar perancangan dan pembuatan prototype berdasarkan kebutuhan yang telah di kumpulkan sebelumnya.

7) Evaluasi dan Uji Coba

Tahap evaluasi dan uji coba atau tahap customer test-drives mock-up dilakukan untuk memastikan aplikasi yang dikembangkan sesuai dengan kebutuhan pengguna. Evaluasi dan uji coba yang dilakukan menggunakan metode perhitungan skala likert untuk mengetahui persentase kebutuhan pengguna terhadap aplikasi yang telah dibuat.

8) Penulisan Laporan Penelitian

Tahap akhir dalam penelitian ini adalah membuat laporan tugas akhir. Laporan ini berisi hal - hal yang dikerjakan selama penelitian dan hasil yang didapatkan pada saat melakukan penelitian.

\section{HASIL DAN PEMBAHASAN}

Hasil dan Pembahasan merupakan bagian yang menjelaskan mengenai hasil dari aplikasi yang telah dirancang dan dibangun sesuai metode dan perancangan sistem. Perancangan proses dalam sistem yang dibangun menggunakan Unified Modeling Language (UML) untuk memberikan gambaran visual, rancangan dan spesifikasi sistem. Beberapa UML yang digunakan dalam sistem ini yaitu, usecase diagram, activity diagram, sequence diagram dan class diagram.

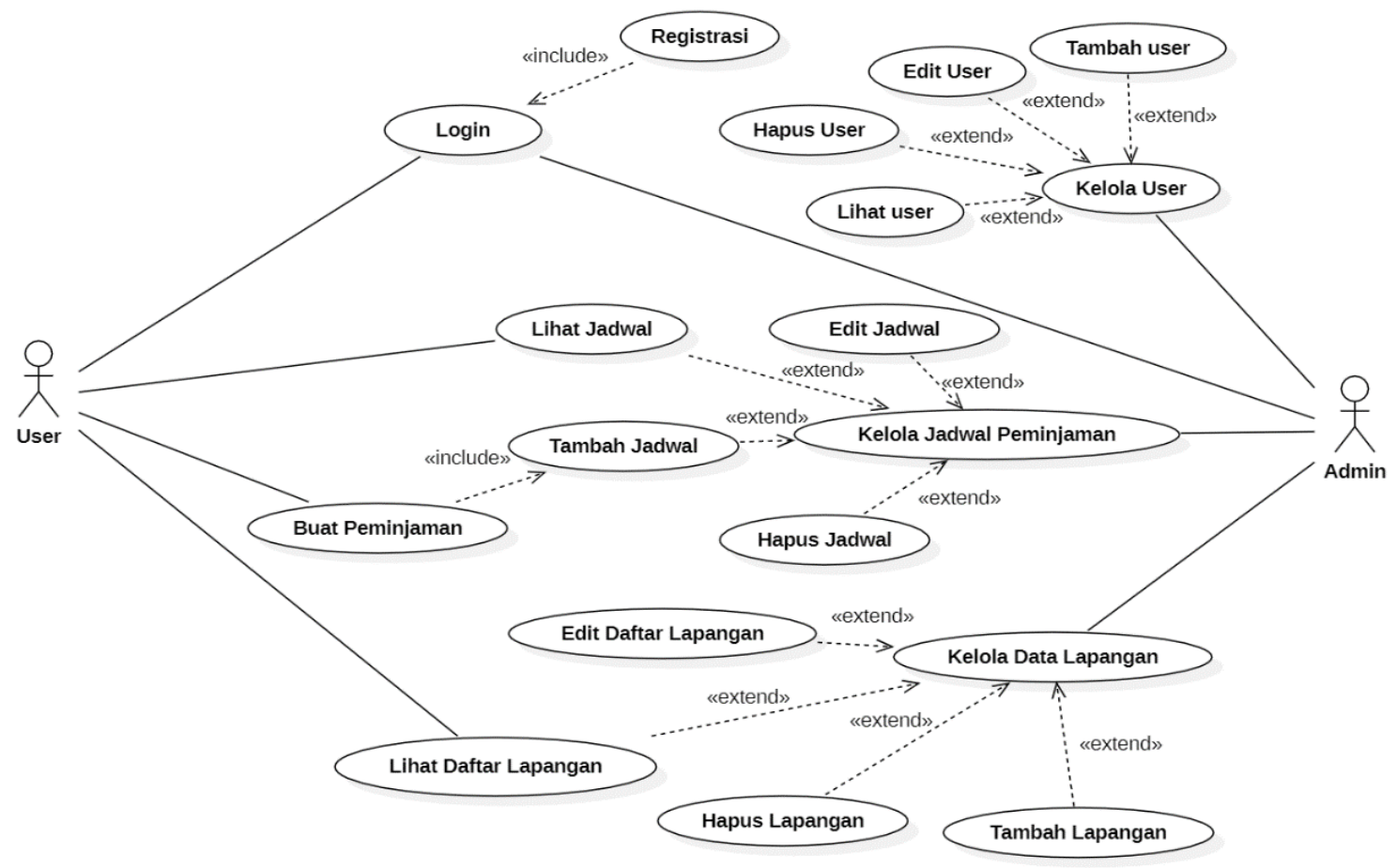

Gambar 3. Use Case Diagram Aplikasi Peminjaman Lapangan Basket UKSW

Kalalinggi, et., al (Perancangan Aplikasi Peminjaman Lapangan Basket Universitas Kristen Satya Wacana Berbasis WEB) 
Gambar 3 merupakan usecase diagram aplikasi peminjaman lapangan basket UKSW. Usecase diagram tersebut terdiri dari 2 (dua) aktor yaitu User dan Admin. User dapat melakukan peminjaman, registrasi, melihat jadwal dan melihat daftar lapangan yang tersedia

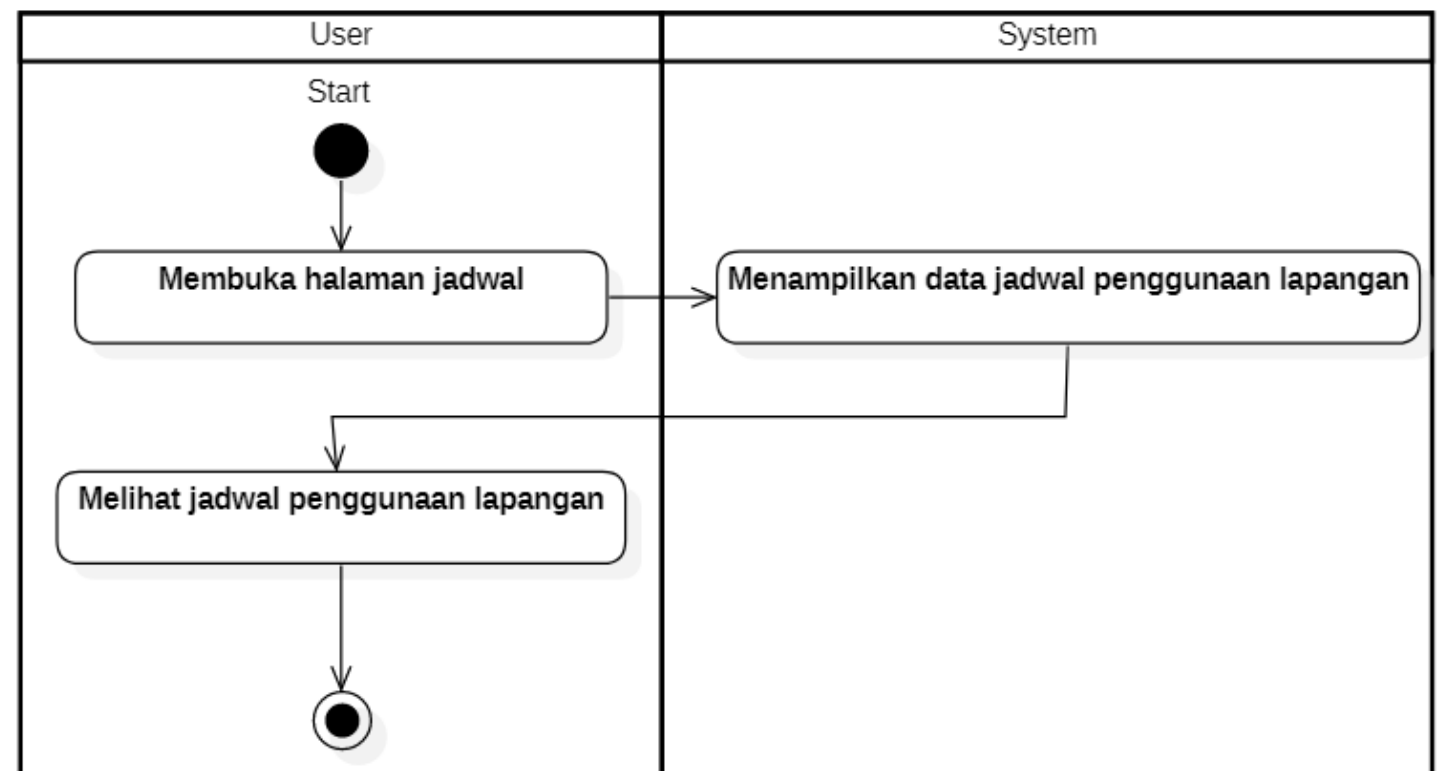

.Gambar 4. Activity Diagram Registrasi

Gambar 4 merupakan diagram activity system yang menunjukkan aktivitas sistem dalam melakukan registrasi sebagai user. Aktivitas ini dimulai dengan sistem menampilkan form registrasi yang kemudian diisi oleh user. Sistem akan melakukan pengecekan apakah data yang dimasukkan sudah lengkap atau belum, apabila belum maka sistem akan kembali ke tampilan form registrasi. Data yang telah diisi lengkap oleh user akan diinputkan kedalam database dan sistem akan menampilkan tampilan login. 


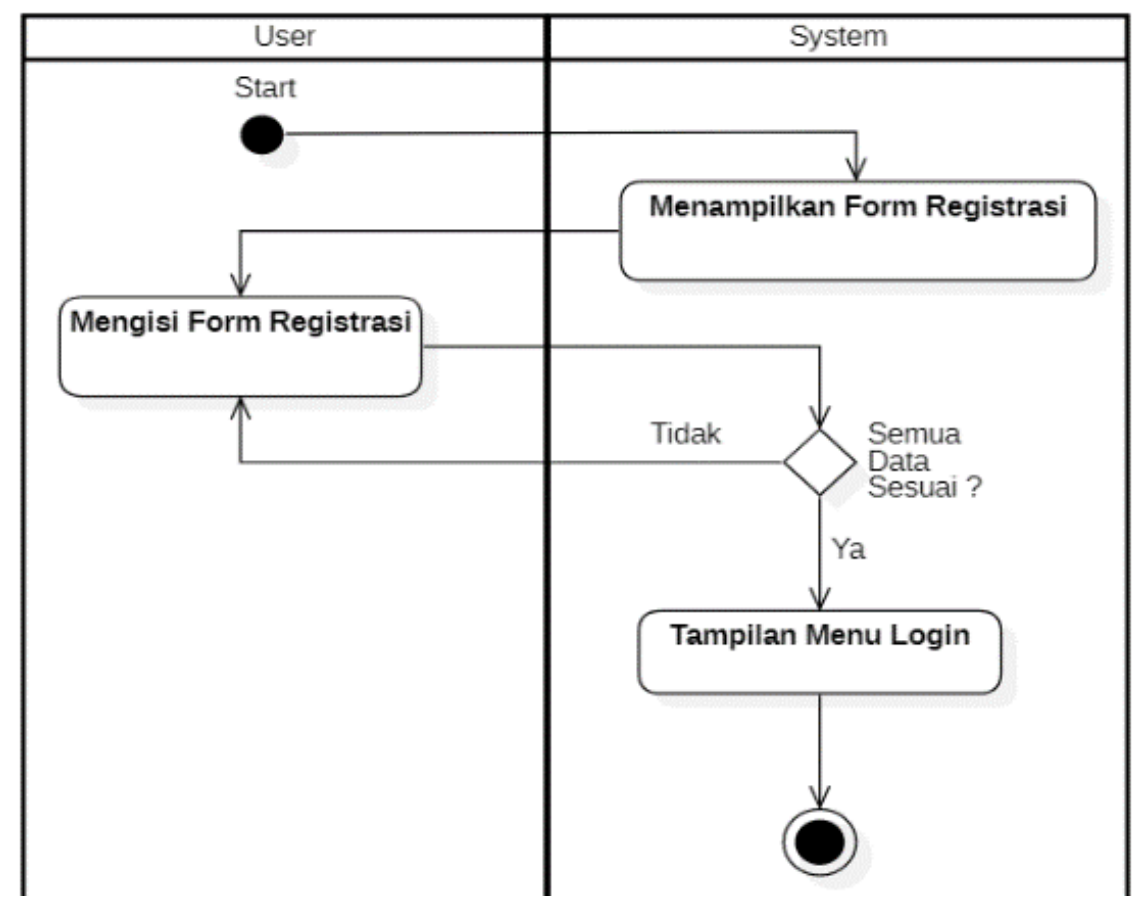

Gambar 5. Activity Diagram Melihat Jadwal oleh User

5 merupakan diagram activity yang menunjukkan aktivitas sistem dalam melihat jadwal sebagai user. Aktivitas ini dimulai dengan user membukan halaman jadwal yang kemudian sistem akan menampilkan data jadwal penggunaan lapangan dan user dapat melihat jadwal penggunaan lapangan.

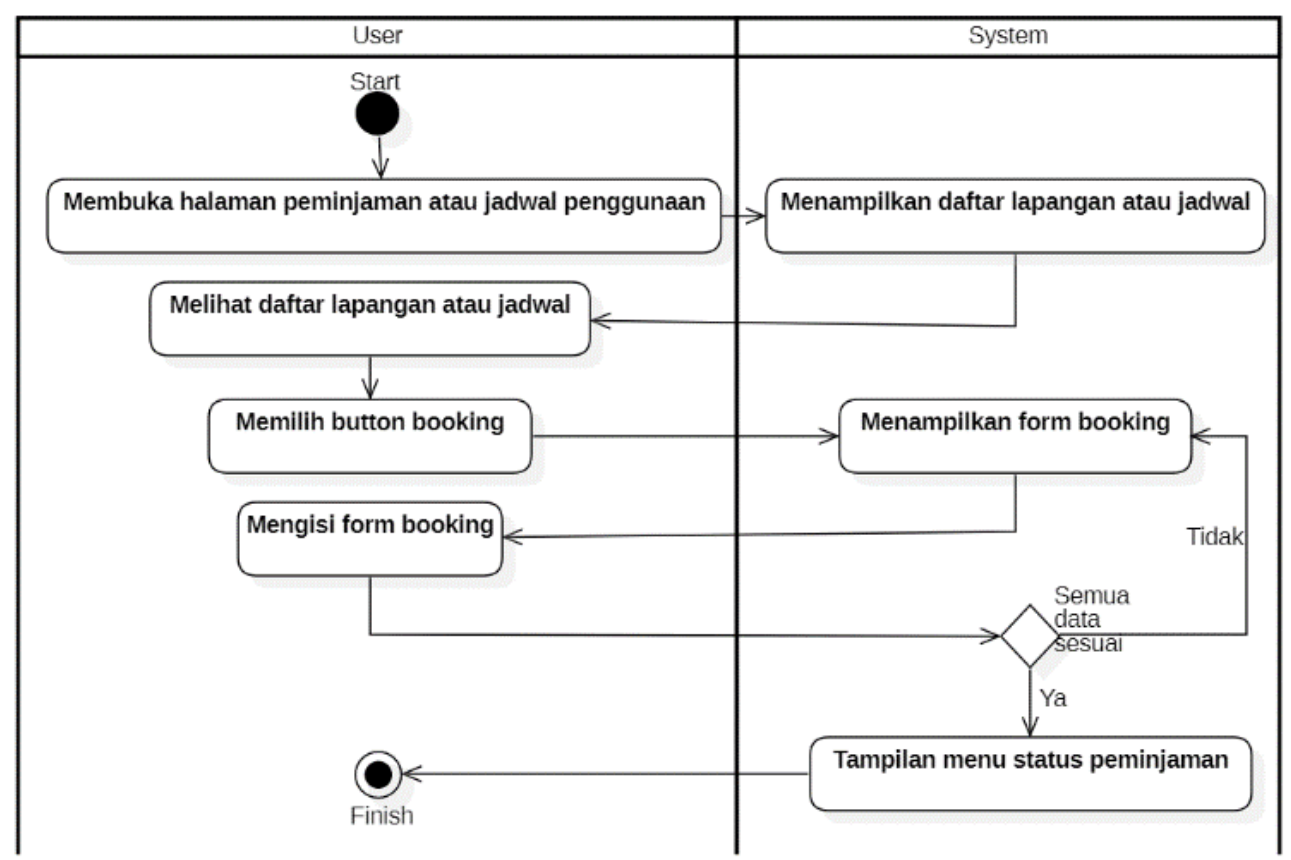

Gambar 6. Activity Diagram Proses Request Peminjaman oleh User

Kalalinggi, et., al (Perancangan Aplikasi Peminjaman Lapangan Basket Universitas Kristen Satya Wacana Berbasis WEB) 
Gambar 6 merupakan activity diagram yang menunjukkan aktivitas proses request peminjaman sebagai user. User masuk ke halaman peminjaman, sistem akan menampilkan halaman peminjaman yang didalamnya berisi daftar lapangan. User memilih lapangan yang akan dipinjam, dan kemudian sistem menampilkan jadwal penggunaan lapangan yang dipilih. Setelah melihat jadwal lapangan yang dipilih, user akan mengklik button booking untuk melakukan peminjaman. Sistem menampilkan form booking, yang selanjutnya diisi oleh user, kemudian dilakukan pengecekan apakah data yang dimasukkan sudah lengkap atau belum, apabila data yang dimasukkan belum lengkap maka sistem akan menampilkan kembali form booking yang akan diisi kembali oleh user. Apabila data yang dimasukkan sudah lengkap, maka sistem akan mengirim ke database dan menampilkan tampilan menu status peminjaman.

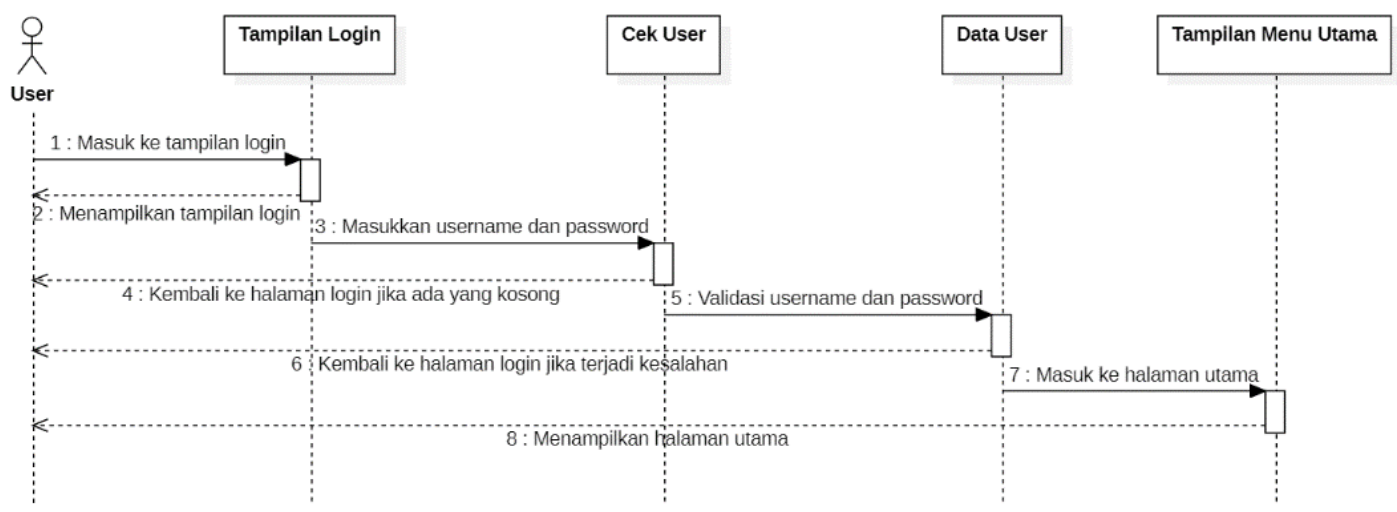

Gambar 7. Sequence Diagram Proses Login oleh User

Gambar 7 merupakan sequence diagram pada saat user melakukan login. User masuk ke halaman login dan mengisi form login dengan username dan password, apabila username atau password ada yang kosong maka pada saat melakukan submit akan terjadi kesalahan dan akan menampilkan halaman login kembali. Pengecekan user akan dilakukan untuk memvalidasi kesesuaian username dan password yang dimasukkan dengan data yang ada di database, jika salah maka sistem akan menampilkan kembali halaman login. Apabila validasi benar, maka sistem akan masuk ke halaman utama dan proses login telah berhasil.

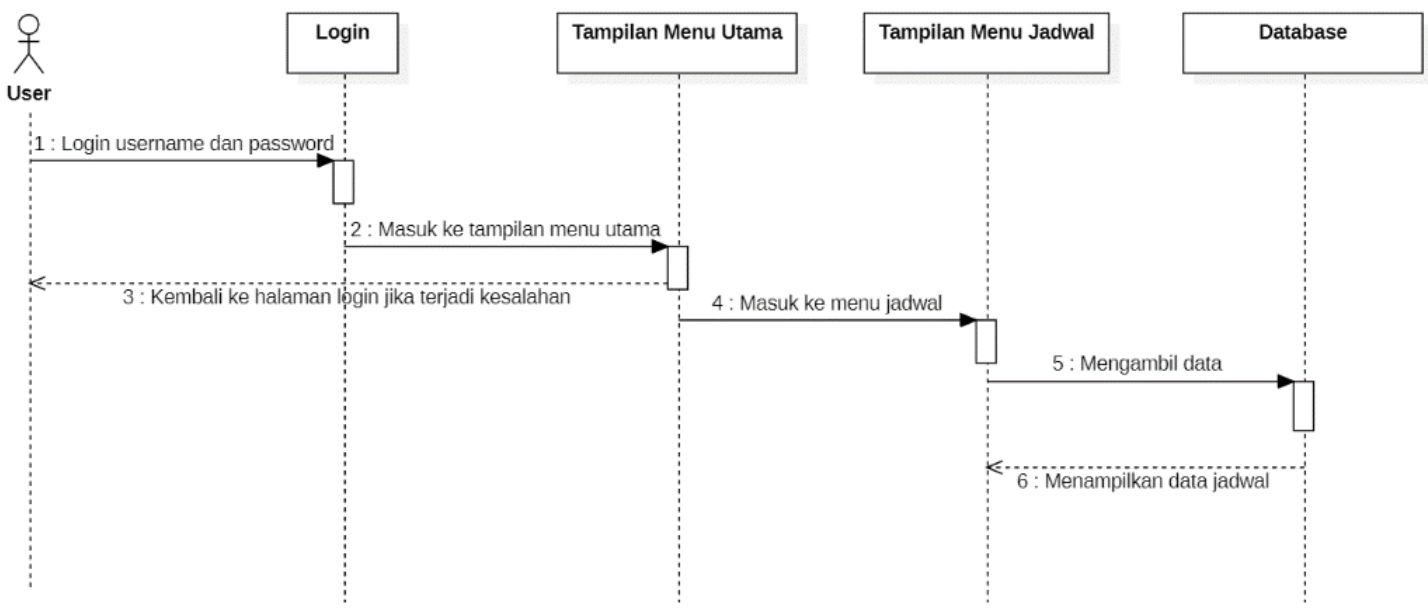

Gambar 8. Sequence Diagram Melihat Jadwal oleh User

Kalalinggi, et., al (Perancangan Aplikasi Peminjaman Lapangan Basket Universitas Kristen Satya Wacana Berbasis WEB) 
Gambar 8 merupakan sequence diagram pada saat user akan melihat jadwal. User akan melakukan login untuk masuk ke halaman menu utama, apabila pada saat login terjadi kesalahan maka sistem akan kembali ke halaman login. Jika berhasil masuk ke tampilan menu utama, user akan masuk ke halaman menu jadwal, sistem secara otomatis akan mengambil data daftar jadwal di database untuk di tampilkan dihalaman menu jadwal.

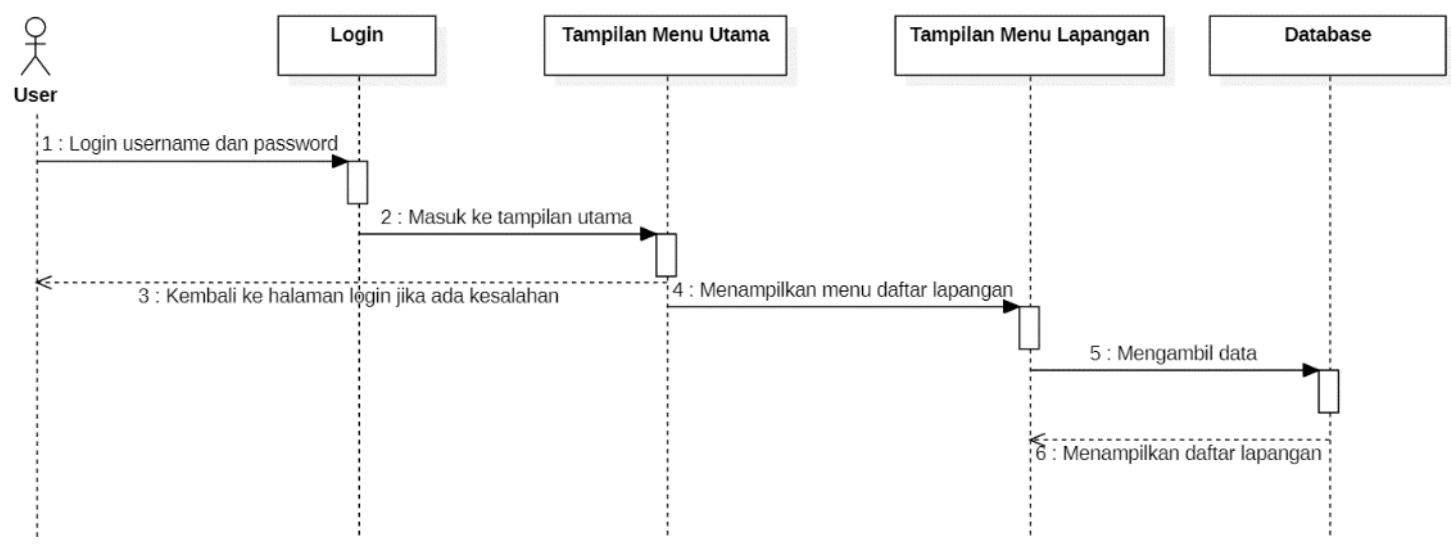

Gambar 9. Sequence Diagram Melihat Daftar Lapangan oleh User

Gambar 9 merupakan sequence diagram pada saat user melakukan proses untuk melihat daftar lapangan. User akan melakukan login untuk masuk ke halaman menu utama, apabila pada saat login terjadi kesalahan maka sistem akan kembali ke halaman login. Jika berhasil masuk ke tampilan menu utama, user akan masuk ke halaman menu lapangan, sistem secara otomatis akan mengambil data daftar lapangan di database untuk di tampilkan dihalaman menu lapangan.

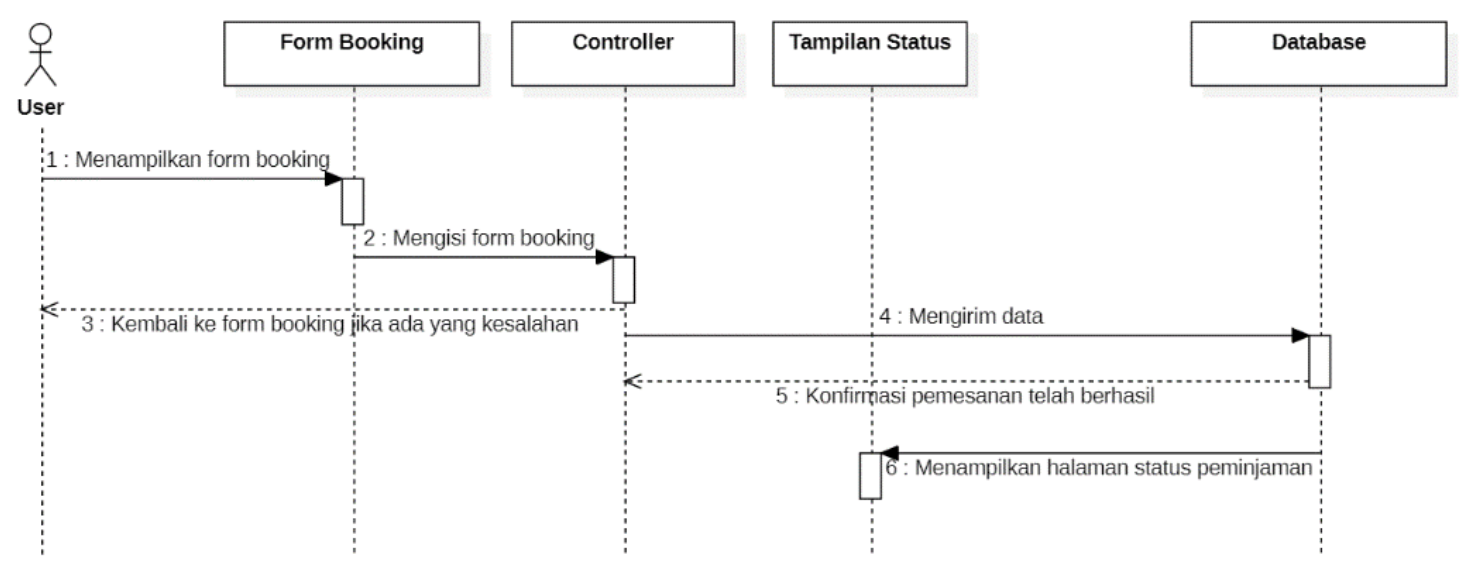

Gambar 10. Sequence Diagram Pemesanan Lapangan oleh User

Gambar 10 merupakan sequence diagram pada saat user akan melakukan pemesanan lapangan. User akan masuk ke tampilan form booking untuk mengisi data - data yang dibutuhkan pada form booking, apabila ada bagian yang belum diisi maka pada saat submit secara otomatis sistem akan menampilkan kembali form booking. Setelah melakukan pengisian pada form booking data akan di kirim ke database untuk menunggu konfirmasi persetujuan dari

Kalalinggi, et., al (Perancangan Aplikasi Peminjaman Lapangan Basket Universitas Kristen Satya Wacana Berbasis WEB) 
admin, sistem akan menampikan halaman status peminjaman untuk melihat status peminjaman yang telah diajukan

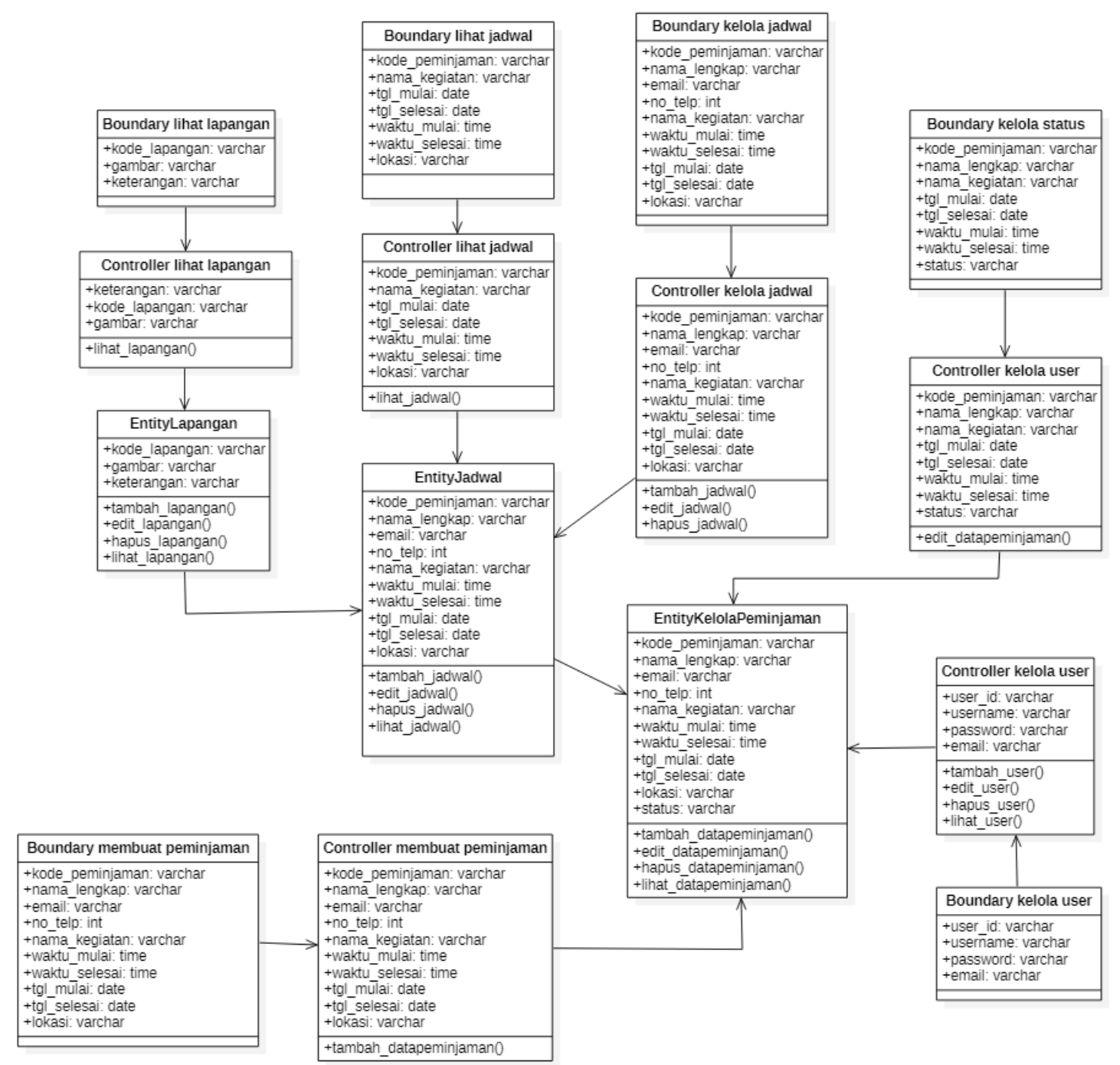

Gambar 11. Class Diagram Aplikasi Peminjaman Lapangan Basket UKSW

Gambar 11 merupakan class diagram dari aplikasi ini dimana terdiri dari atas 3 bagian utama yaitu entity, controller, dan boundary. Dalam sistem ini terdapat 3 entity yaitu entity lapangan, entity jadwal, dan entity kelola peminjaman. Controller terdiri dari controller lihat lapangan, controller lihat jadwal, controller kelola jadwal, controller kelola user, controller membuat peminjaman dan controller kelola user. Controller-controller tersebut akan menangani ketiga entity yang ada sesuai dengan atributnya masing-masing.

Aplikasi berbasis web yang telah dibangun dapat melakukan proses peminjaman lapangan dan memberikan informasi terkait jadwal penggunaan lapangan yang ada. Peminjaman lapangan hanya dapat dilakukan apabila user telah melakukan registrasi dan terdaftar sebagai user. User dapat melihat jadwal penggunaan lapangan sehingga pada saat melakukan pengajuan peminjaman dapat memilih waktu yang tidak bersamaan dengan peminjam yang lain. Sistem juga membantu admin untuk mengatur jadwal penggunaan lapangan sehingga pengajuan jadwal

Kalalinggi, et., al (Perancangan Aplikasi Peminjaman Lapangan Basket Universitas Kristen Satya Wacana Berbasis WEB) 
dapat ditolak atau disetujui oleh admin. Aplikasi ini dapat digunakan oleh admin untuk menginputkan langsung jadwal penggunaan lapangan, pengguna aplikasi dan ketersediaan lapangan. Oleh karena itu, berdasarkan perancangan yang telah dirancang sebelumnya dihasilkan sebuah aplikasi peminjaman lapangan berbasis web.

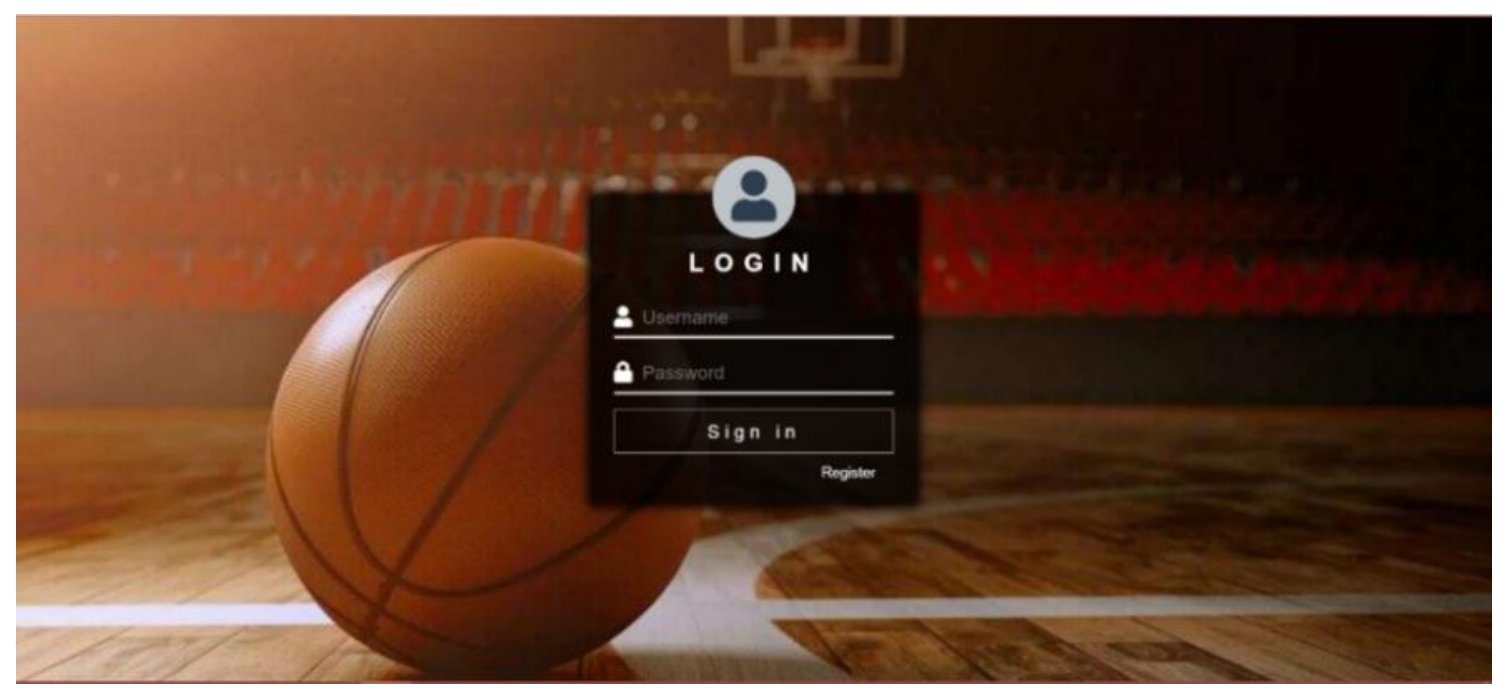

Gambar 12. Form Login

Gambar 12 merupakan tampilan form login aplikasi. Form ini dapat digunakan oleh user maupun admin untuk mengakses dan menggunakan aplikasi ini. Username dan password yang digunakan oleh user merupakan username dan password yang telah didaftarkan pada saat registrasi.
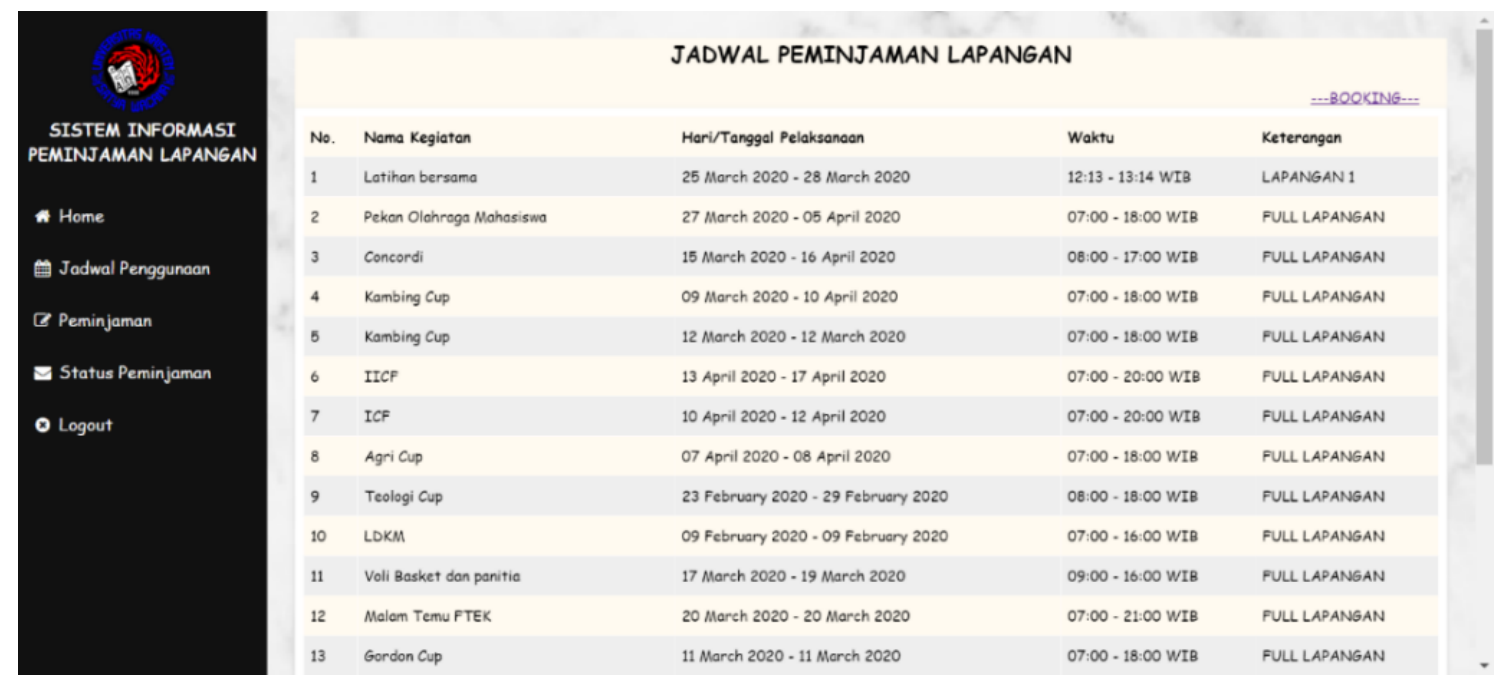

Gambar 13. Tampilan Jadwal Penggunaan Lapangan

Gambar 13 merupakan gambar tampilan halaman jadwal penggunaan lapangan. Pada halaman tersebut terdapat daftar - daftar beserta waktu penggunaan yang telah di setujui oleh admin dan dapat dilihat oleh user sebelum melakukan pemesanan lapangan.

Kalalinggi, et., al (Perancangan Aplikasi Peminjaman Lapangan Basket Universitas Kristen Satya Wacana Berbasis WEB) 


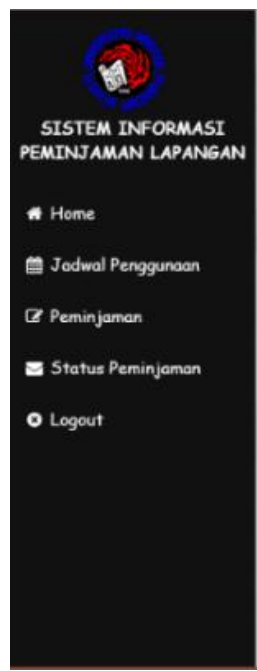

\section{PEMINJAMAN}

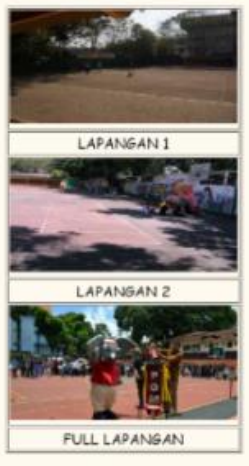

Lerut Armac || mookmo

Gambar 14. Tampilan daftar lapangan

Gambar 14 merupakan tampilan daftar lapangan yang ada pada tampilan user. User dapat melihat daftar lapangan dan langsung melakukan pemesanan dengan mengklik button booking atau melihat jadwal penggunaan dengan mengklik button lihat jadwal yang tersedia.

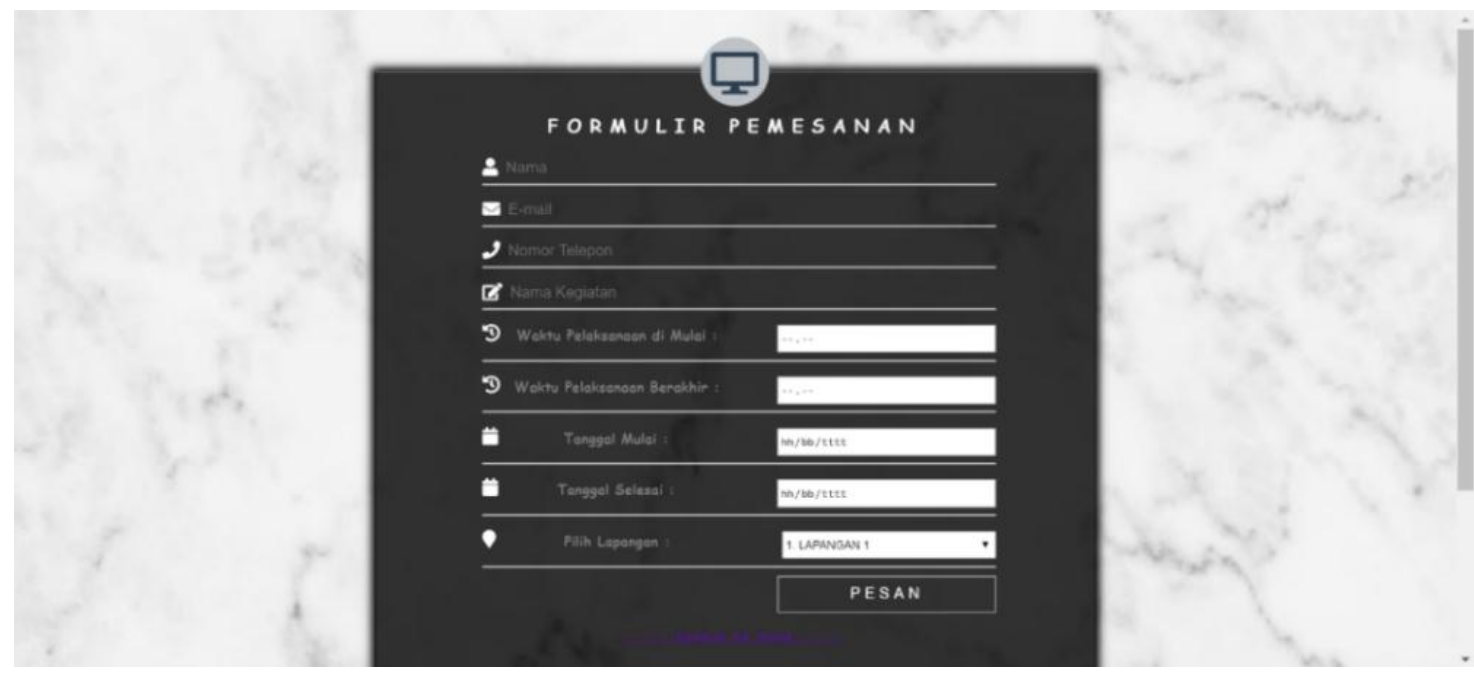

Gambar 15. Form Pemesanan Lapangan

Gambar 15 merupakan form pemesanan lapangan yang dapat diisi oleh user pada saat akan melakukan pemesanan lapangan. Data yang dimasukkan oleh user akan dimasuk ke database dan dapat diakses oleh admin pada saat akan menyetujui pemesanan lapangan. 

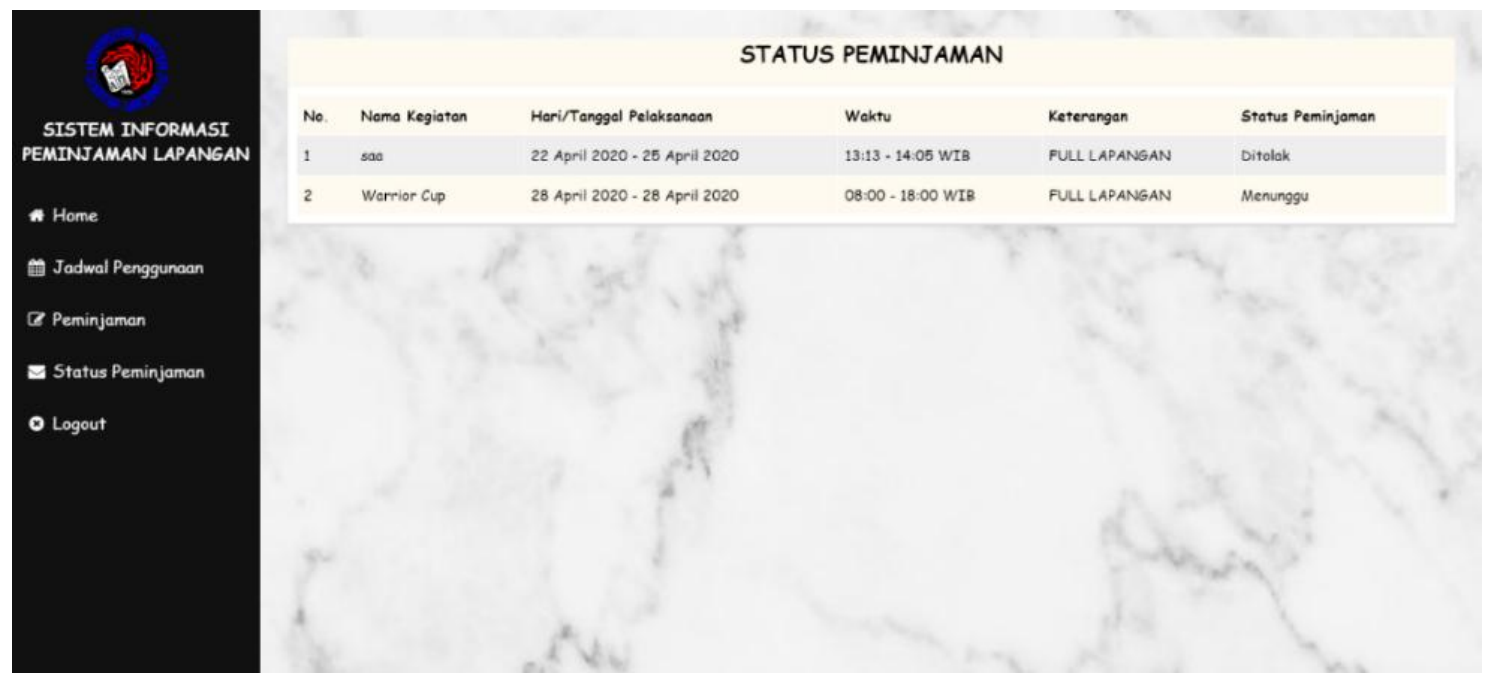

Gambar 16. Tampilan Status Peminjaman

Gambar 16 merupakan tampilan halaman status peminjaman yang menampilkan daftar peminjaman yang sedang menunggu persetujuan admin dan daftar peminjaman yang ditolak oleh admin.

Pengujian sistem yang dilakukan pada aplikasi peminjaman lapangan basket Universitas Kristen Satya Wacana menggunakan perhitungan skala likert dari hasil kuisioner yang telah dibagikan dan diisi oleh responden. Pengujian ini dilakukan dengan memberikan kuisioner kepada 10 responden untuk mendapatkan hasil penilaian yang subjektif. Pengujian diawali dengan melakukan demo aplikasi kepada para responden dan memberikan kesempatan kepada para responden untuk mencoba menggunakan berbagai fungsi aplikasi. Kuisioner yang telah dibagian kepada para responden akan diisi dan dikembalikan kepada penulis untuk dikelola berdasarkan perhitungan skala likert. Standar penilaian yang digunakan untuk mengetahui bagus atau tidaknya nilai parameter yang diperoleh dapat dilihat pada tabel sebagai berikut.

Tabel 1. Parameter Nilai [12]

\begin{tabular}{|c|c|}
\hline Skor & Nilai \\
\hline 1 & Sangat Tidak Setuju \\
\hline 2 & Tidak Setuju \\
\hline 3 & Netral \\
\hline 4 & Setuju \\
\hline 5 & Sangat Setuju \\
\hline
\end{tabular}

Tabel 1 merupakan tabel yang menunjukkan jenis parameter yang digunakan dalam pengisian kuisioner yang dibagikan kepada para responden. Responden mengisi kuisioner berdasarkan nilai yang sudah di tentukan. Dalam tabel tersebut terdapat 5 (lima) parameter nilai yang dapat dipilih oleh para responden.

Tabel 2. Hasil Kuisioner Pengujian Aplikasi

\begin{tabular}{|c|c|c|c|c|c|c|c|c|c|c|}
\hline \multirow{2}{*}{ No. } & \multirow{8}{*}{ Pertanyaan } & \multicolumn{7}{c|}{ Jawaban Responden } & \multirow{2}{*}{ Jumlah } & Indeks \\
\cline { 2 - 5 } & Ax1 & Ax2 & Ax3 & Ax4 & Ax5 & \\
\hline \multicolumn{8}{|c|}{ User Interface } \\
\hline 1. & $\begin{array}{l}\text { Apakah penggunaan menu atau } \\
\text { fitur aplikasi menu mudah }\end{array}$ & 0 & 0 & 0 & 5 & 5 & 45 & $90 \%$ \\
\hline
\end{tabular}

Kalalinggi, et., al (Perancangan Aplikasi Peminjaman Lapangan Basket Universitas Kristen Satya Wacana Berbasis WEB) 


\begin{tabular}{|c|c|c|c|c|c|c|c|c|}
\hline & digunakan? & & & & & & & \\
\hline 2. & $\begin{array}{l}\text { Apakah aplikasi mudah } \\
\text { dioperasikan? }\end{array}$ & 0 & 0 & 0 & 1 & 9 & 49 & $98 \%$ \\
\hline 3. & $\begin{array}{l}\text { Apakah tampilan menu dalam } \\
\text { aplikasi mudah untuk dikenali ? }\end{array}$ & 0 & 0 & 0 & 5 & 5 & 45 & $90 \%$ \\
\hline & Total & 0 & 0 & 0 & 11 & 19 & 139 & $92 \%$ \\
\hline \multicolumn{9}{|c|}{ Fungsionalitas } \\
\hline 4. & $\begin{array}{l}\text { Apakah aplikasi ini sesuai dengan } \\
\text { kebutuhan? }\end{array}$ & 0 & 0 & 0 & 5 & 5 & 45 & $90 \%$ \\
\hline 5. & $\begin{array}{l}\text { Apakah aplikasi bermanfaat bagi } \\
\text { pengguna? }\end{array}$ & 0 & 0 & 0 & 3 & 7 & 47 & $94 \%$ \\
\hline 6. & $\begin{array}{l}\text { Apakah fungsi pemesanan } \\
\text { lapangan dapat berjalan dengan } \\
\text { baik? }\end{array}$ & 0 & 0 & 0 & 3 & 7 & 47 & $94 \%$ \\
\hline 7. & $\begin{array}{l}\text { Apakah aplikasi memberikan } \\
\text { informasi yang mudah dipahami ? }\end{array}$ & 0 & 0 & 0 & 3 & 7 & 47 & $94 \%$ \\
\hline \multirow{2}{*}{\multicolumn{2}{|c|}{$\begin{array}{c}\text { Total } \\
\text { Total Keseluruhan Indeks }\end{array}$}} & 0 & 0 & 0 & 14 & 26 & 186 & $93 \%$ \\
\hline & & & & & & & 46 & $92 \%$ \\
\hline
\end{tabular}

Tabel 2 merupakan hasil pengujian aplikasi melalui kuisioner yang telah dibagikan kepada responden. Berdasarkan hasil pengujian tersebut diperoleh hasil yaitu nilai rata - rata pada jawaban pertama yaitu 4,5 maka persentasenya adalah $90 \%$, nilai rata - rata pada jawabana kedua yaitu 4,9 maka persentasenya adalah $98 \%$, nilai rata - rata jawaban ketiga yaitu 4,5 maka persentasenya adalah 90\%, nilai rata - rata pada jawaban keempat yaitu 4,5 maka persentasenya adalah $90 \%$, nilai rata - rata pada jawaban kelima yaitu 4,7 maka persentasenya adalah $94 \%$, nilai rata - rata pada jawaban keenam yaitu 4,7 maka persentasenya adalah $94 \%$ dan nilai rata rata pada jawaban ketujuh yaitu 4,7 maka persentasenya adalah 94\%. Berdasarkan perhitungan Likert, maka indeks yang diperoleh untuk klasifikasi User Interface adalah 92,6\%. Dan indeks untuk klasifikasi Fungsionalitas adalah 93\%. Total keseluruhan indeks untuk kedua klasifikasi tersebut yaitu $92,8 \%$. Berdasarkan indeks persentase yang diperoleh dapat disimpulkan bahwa para responden setuju dengan manfaat adanya aplikasi peminjaman, membantu para pengguna dalam mengakses dan melakukan proses peminjaman.

\section{KESIMPULAN}

Berdasarkan hasil penelitian yang telah dilakukan dapat disimpulkan bahwa Perancangan Aplikasi Peminjaman Lapangan Basket Universitas Kristen Satya Wacana Berbasis Web ini untuk menjawab kebutuhan mahasiswa, dosen dan staff dalam melakukan peminjaman lapangan serta mengelola jadwal penggunaan lapangan. Aplikasi ini dibangun menggunakan Bahasa pemrograman PHP dan HTML serta MySQL sebagai database. Berdasarkan hasil pengujian aplikasi yang telah dilakukan menggunakan metode perhitungan skala likert diperoleh total keseluruhan indeks user interface dan fungsionalitas yaitu 92,8\%, sehingga dapat disimpulkan bahwa aplikasi yang dibuat telah memenuhi kebutuhan pengguna dalam melakukan pemesanan lapangan, aplikasi peminjaman lapangan basket dapat mempermudah civitas akademika Universitas Kristen Satya Wacana dalam melakukan peminjaman lapangan secara online dan aplikasi peminjaman lapangan basket dapat mempermudah pihak kampus dalam mengelola dan mengatur jadwal penggunaan lapangan basket. 


\section{SARAN}

Saran yang diberikan terhadap penelitian lebih lanjut yaitu pengembangan aplikasi dapat dilakukan dengan memperluas jenis lapangan atau tempat yang dapat dipinjam oleh pengguna aplikasi sehingga proses peminjaman dapat dilakukan untuk berbagai jenis tempat, ruangan atau alat - alat. Selain itu dapat menambahkan beberapa fitur seperti profil pengguna atau berita online seputar kampus.

\section{UCAPAN TERIMA KASIH}

Penulis mengucapkan terima kasih kepada Tuhan Yang Maha Esa atas kasih dan penyertaan-Nya sehingga penulis dapat menyelesaikan penulisan jurnal ini.

\section{DAFTAR PUSTAKA}

[1] “Arti kata lapang - Kamus Besar Bahasa Indonesia (KBBI) Online.” [Online]. Available: https://kbbi.web.id/lapang. [Accessed: 02-Dec-2019].

[2] Setiawan, R., \& Soraya, I. 2001. Rancang Bangun Aplikasi Peminjaman Ruangan Berbasis Web dan SMS Gateway (Landing Room System Development Using Web and SMS Gateway Approach). Jurnal Teknologi Informasi, 4(2), 12.

[3] Ruse, A. A., \& Mailoa, E. 2016. Perancangan Aplikasi Pemesanan Lapangan Futsal Berbasis Web Di Salatiga Artikel Ilmiah Program Studi Teknik Informatika Fakultas Teknologi Informasi Universitas Kristen Satya Wacana Salatiga April 2016 Perancangan Aplikasi Pemesanan Lapangan Futsal Berbasis.

[4] Sahrun, N. 2019. Perancangan dan Implementasi Sistem Informasi Manajemen Aset pada Pemerintah Kabupaten Merangin Menggunakan Bahasa Pemrograman Php dan Mysql. Jurnal Teknologi Dan Sistem Informasi Bisnis, 1(1), 1-6.

[5] Faridi, F., Safitri, M., \& Matusin, P. R. 2018. Sistem Aplikasi Peminjaman Dokumen Customer Berbasis Web Pada PT. Lippo Karawaci, Tbk. IJCIT (Indonesian Journal on Computer and Information Technology), 3(2).

[6] Widodo, T. 2018. Sistem Pemesanan Penggunaan Lapangan Futsal Dengan Algoritma First Come First Served Berbasis Website (Studi Kasus Bardosono Happy Futsal Yogyakarta) (Doctoral dissertation, Universitas Teknologi Yogyakarta).

[7] Yusuf, D. 2017. Sistem Peminjaman Barang Di Perusahaan Menggunakan Teknologi RFID. SIGMA-Jurnal Teknol. Pelita Bangsa, 6(1), 49-58.

[8] Munandar, A. 2016. Perancangan Aplikasi Penjualan Berbasis Web Pada Toko Sport Ipal. PROCIDING KMSI, 4(1).

[9] Nugraha, W., \& Syarif, M. 2018. Penerapan Metode Prototype Dalam Perancangan Sistem Informasi Penghitungan Volume Dan Cost Penjualan Minuman Berbasis Website. JUSIM (Jurnal Sistem Informasi Musirawas), 3(02), 97-105.

Kalalinggi, et., al (Perancangan Aplikasi Peminjaman Lapangan Basket Universitas Kristen Satya Wacana Berbasis WEB) 
[10] Pradipta, A. A., Prasetyo, Y. A., \& Ambarsari, N. 2015. Pengembangan Web ECommerce Bojana Sari Menggunakan Metode Prototype.eProceedings of Engineering, 2(1).

[11] Anggraeni, E. Y. 2017. Pengantar Sistem Informasi. Andi.Yogyakarta.

[12] Nazir, M. 2005. Metode Penelitian Cetakan Keenam. Ghalia Indonesia. Jakarta. 